\title{
Applications and Limitations of Neuro-Monitoring in Paediatric Anaesthesia and Intravenous Anaesthesia: A Narrative Review
}

\author{
Chiara Grasso $^{1}$ (D), Vanessa Marchesini ${ }^{2}$ and Nicola Disma ${ }^{1, *(\mathbb{D})}$ \\ 1 Unit for Research \& Innovation, Department of Paediatric Anaesthesia, IRCCS Istituto Giannina Gaslini, \\ 16147 Genova, Italy; chiara.grasso210@gmail.com \\ 2 Paediatric Intensive Care Unit, Royal Melbourne Children's Hospital, Parkville 3052, Australia; \\ vane.marchesini@gmail.com \\ * Correspondence: NicolaDisma@Gaslini.org
}

check for updates

Citation: Grasso, C.; Marchesini, V.; Disma, N. Applications and

Limitations of Neuro-Monitoring in Paediatric Anaesthesia and Intravenous Anaesthesia: A Narrative Review. J. Clin. Med. 2021, 10, 2639. https://doi.org/10.3390/jcm10122639

Academic Editor: Keira P. Mason

Received: 17 May 2021

Accepted: 11 June 2021

Published: 15 June 2021

Publisher's Note: MDPI stays neutral with regard to jurisdictional claims in published maps and institutional affiliations.

Copyright: (c) 2021 by the authors. Licensee MDPI, Basel, Switzerland. This article is an open access article distributed under the terms and conditions of the Creative Commons Attribution (CC BY) license (https:/ / creativecommons.org/licenses/by/ $4.0 /)$.

\begin{abstract}
Safe management of anaesthesia in children has been one of the top areas of research over the last decade. After the large volume of articles which focused on the putative neurotoxic effect of anaesthetic agents on the developing brain, the attention and research efforts shifted toward prevention and treatment of critical events and the importance of peri-anaesthetic haemodynamic stability to prevent negative neurological outcomes. Safetots.org is an international initiative aiming at raising the attention on the relevance of a high-quality anaesthesia in children undergoing surgical and non-surgical procedures to guarantee a favourable outcome. Children might experience hemodynamic instability for many reasons, and how the range of normality within brain autoregulation is maintained is still unknown. Neuro-monitoring can guide anaesthesia providers in delivering optimal anaesthetic drugs dosages and also correcting underling conditions that can negatively affect the neurological outcome. In particular, it is referred to EEG-based monitoring and monitoring for brain oxygenation.
\end{abstract}

Keywords: neuromonitoring; EEG-derived monitor; depth of anaesthesia; near-infrared-spectroscopy; brain oxygenation; anaesthesia; paediatric

The present narrative review aims at presenting current available monitoring of depth of anaesthesia and brain oxygenation and critically discussing their application in the paediatric clinical setting.

\section{EEG-Based Anaesthesia Depth Monitoring}

The monitoring of hypnosis depth by means of electroencephalogram-based (EEGbased) systems is emerging in paediatric anaesthesia common practice. This monitor system measures specific EEG signs which derive from anaesthetic-induced changes in neuronal firing.

In children, these signs are influenced not only by both the depth of sedation and the mechanism of action of the specific anaesthetic agent, but also by the typical agerelated changes of a developing brain [1]. Moreover, the current clinical condition and underlying co-morbidities might significantly affect the validation and application of this monitoring [2-4]. Therefore, although recent studies have shown that they are worth being used in children [5], many of the available monitoring methods show limitations when applied to paediatric patients and have to be cautiously used, especially in those aged less than 1 year [6-8].

\subsection{Available $E E G_{S}$ Technology}

For daily practice, in addition to the unprocessed EEG (the raw cortical EEG), two different groups of EEG-based devices are currently available. These are the EEG-derived indices (processed EEG or p-EEG) and the spectrogram or Density Spectral Array (DSA) [9] (Figure 1). 


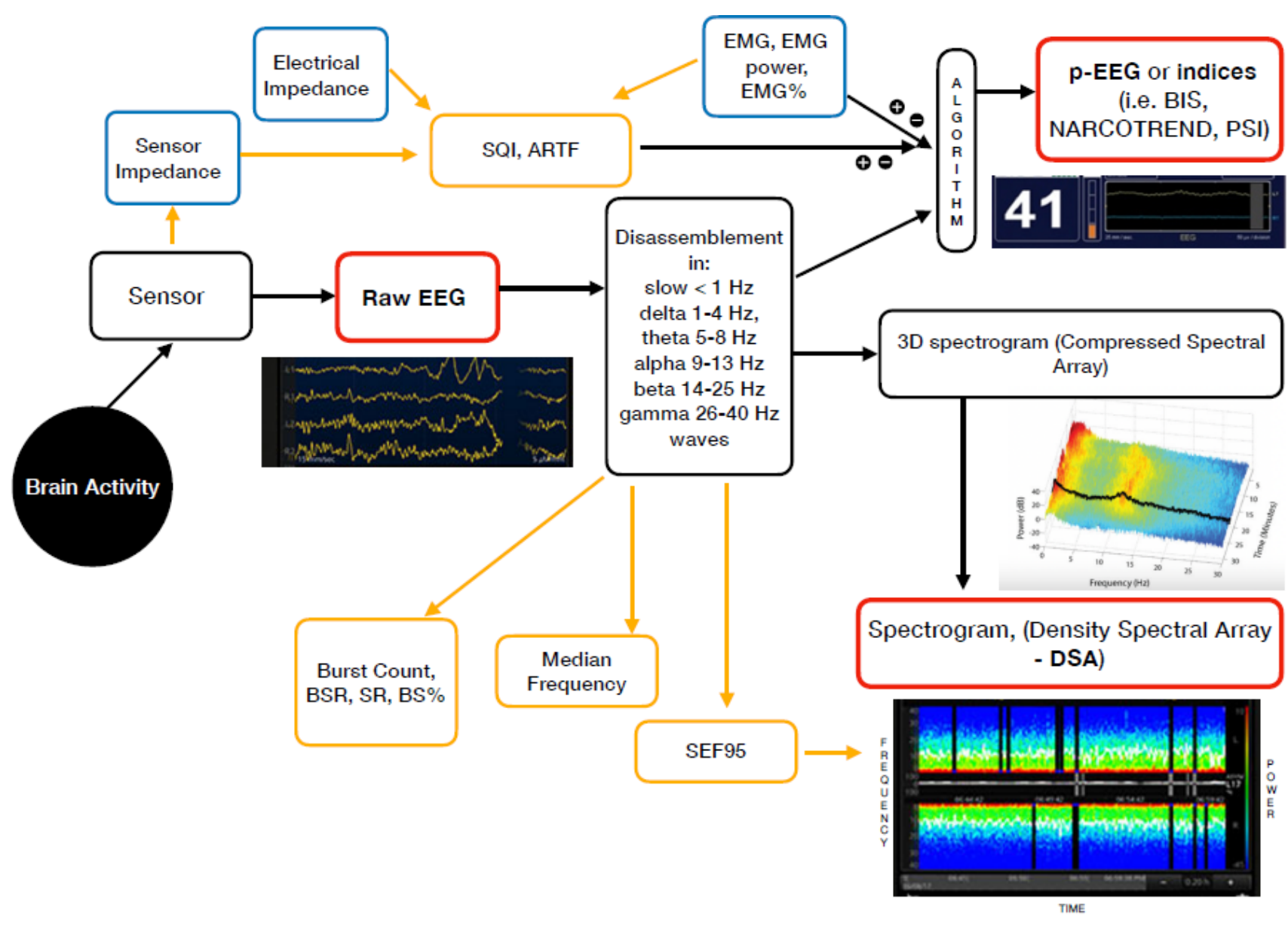

Figure 1. Mechanism of action of the currently available EEG derived anaesthesia monitoring (in red). The sensor is placed on the forehead and records the electrical potentials produced in the cortex resulting in the raw EEG. The majority of the EEG-derived monitors work by disassembling a complex EEG waveform (the raw EEG), into many series of waves of different frequencies (Hertz-Hz). These, together with several of the EEG variables, are converted into a single index through mathematical algorithms by the processed EEG (p-EEG) devices. The obtained index represents the level of hypnosis. However, the index can also be affected by the Electromyography (EMG) and the Signal Quality Index (SQI or ARTF). The spectrogram, is a real time monitoring which portrays all the EEG frequencies and their power over the time in a three-dimensional method (3D spectrogram or Compressed Spectral Array). The latter is then integrated in a two-dimensional plot using colours to represent different powers in the Density Spectral Array (DSA). Derived additional parameters are the Spectral Edge Frequency (SEF95), Median Frequency and the Burst Count (burst/minute) Suppression Rate (SR), Burst Suppression Ratio (BSR), Suppression Ratio (SR) or BS\% Indicator (Burst suppression percentage). These can be either represented on the display by a number or visualized on the Spectrogram.

The majority of the EEG-derived monitors works by disassembling a complex EEG waveform (the raw EEG), into many series of waves of different frequencies. These are, respectively, the slow $(<1 \mathrm{~Hz})$, delta $(1-4 \mathrm{~Hz})$, theta $(4-8 \mathrm{~Hz})$, alpha $(8-13 \mathrm{~Hz})$, beta $(13-25 \mathrm{~Hz})$ and gamma $(25-40 \mathrm{~Hz})$ oscillations. The power of each band is defined by quantity and amplitude [9].

The processed EEG (p-EEG) devices convert several of the EEG variables into a single index through mathematical algorithms. The obtained index represents the level of hypnosis. Some examples of p-EEG monitors are the Bispectral Index Monitor (BIS, Medtronic Inc., Dublin, Ireland), the Patient State Index (PSI, Masimo Inc., Irvine, CA, USA) of the SEDLine brain function monitor or the Narcotrend index (Narcotrend Inc., Hannover, Germany). The Spectral Edge Frequency (SEF95) is a common EEG-processed parameter, which represents the frequency containing $95 \%$ of the power. Finally, the 
Response and the State Entropy measures the degree of disorder in the EEG together with the electromyography (EMG) signals [10].

Differently from the pEEG, the Density Spectral Array (DSA) or spectrogram is a real time monitoring method which portrays all the EEG frequencies and their power over the time in a three-dimensional method. The latter is then integrated in a two-dimensional plot using colours to represent different powers [11].

Table 1 lists some of the most widely used EEG-based anaesthesia monitoring devices which are currently available, along with their key features.

\subsection{Clinical Application}

The EEG ranges from a wakefulness pattern characterised by beta $(13-25 \mathrm{~Hz})$ and gamma $(25-40 \mathrm{~Hz})$ oscillations, to an isoelectric pattern, which represents an anaestheticinduced coma with profound hypothermia [9]. An unconscious brain under surgical anaesthesia usually shows slow $(<1 \mathrm{~Hz})$ and alpha $(8-13 \mathrm{~Hz})$ oscillation. After induction of anaesthesia or in case of excessive sedation, slow oscillation or occasional burst suppression can occur. However, the EEG pattern also differs in relation to the anaesthetic drug administered. In this way, the DSA allows a trained anaesthetist to easily identify the specific patterns which correspond to certain hypnosis depth and anaesthesia trends $[9,12]$.

Since the EEG-based devices correlate with the amount of both volatile and intravenous anaesthesia, they can predict the patient's state of consciousness or unconsciousness [7]. They should lead to a better control of anaesthesia depth which, in turn, allows avoiding both over-sedation and light-anaesthesia [13,14]. In adults, this has been proven not only to reduce time to emergence, tracheal tube removal, and time to PACU discharge but also in decreasing post-operative nausea and vomiting and delirium as well as in lowering the overall amount of anaesthesia given. [15-17].

In children, only a few studies have analysed correlations between EEG-based monitors and the post-anaesthesia outcome [18-21]. Moreover, the currently available devices for the paediatric population are all based on algorithms which have been tested on adults [7].

Notwithstanding, some studies demonstrate that BIS and Narcotrend monitors are associated with a reduced emergence time and a decreased discharge-time from PACU after paediatric general anaesthesia $[18,19]$. However, discordant results have been found in a randomised trial on the same topic in paediatric cardiac patients [20]. Although a correlation between the use of $\mathrm{pEEG}$ devices and the reduction of awareness episodes has not been clearly demonstrated in children, the anaesthesia monitoring is considered to be also useful in this area [21]. An ongoing prospective, observational, multicentre study aims to further investigate the role of EEG monitoring in infants younger than 36 months. The study observes the incidence of isoelectric EEG events (defined as EEG amplitude less than $20 \mu \mathrm{V}$ for $2 \mathrm{~s}$ or more) and its association with neurological outcome and quality of life in children undergoing at least $30 \mathrm{~min}$ of inhalational or propofol-based general anaesthesia [22].

Despite some studies demonstrated that EEG-based monitoring devices appropriately correlate with specific EEG signs during sevoflurane and propofol anaesthesia in children older than 1 year of age $[5,13]$, the paramount evidence of their beneficial effects is mostly related to total intravenous anaesthesia and propofol (TIVA). In fact, a linear slowing of EEG and a lowering of BIS index has been demonstrated concurrently with the increasing in propofol blood concentration in children [5].

A survey of European paediatric anaesthetist in 2018 showed that the main application of EEG monitoring occurs during TIVA and in children over 4 years of age, with the aim of avoiding awareness [23]. Furthermore, the use of TIVA has recently emerged into the common practice of paediatric anaesthesia. However, despite fairly reliable models, doubts still exist regarding the pharmacokinetic and pharmacodynamic variability of anaesthetic agents among different ages. In this scenario, the use of anaesthesia depth monitoring systems results very useful, especially when the TIVA is associated with Neuromuscular Blockers (NMBs) [24] 


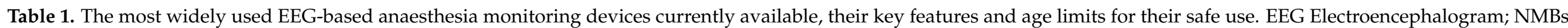
Neuromuscular Blockers; EMG Electromyography; DSA Density Spectral Array; not safe = no studies demonstrate its accuracy and reliability in this age group.

\begin{tabular}{|c|c|c|c|c|c|c|c|c|}
\hline Device & $\begin{array}{l}\text { EEG-Derived } \\
\text { Index } \\
\text { (Processed } \\
\text { EEG) }\end{array}$ & $\begin{array}{l}\text { Mechanism of } \\
\text { Action-Algorhytm Basis }\end{array}$ & $\begin{array}{c}\text { Anaesthesia } \\
\text { Range (Total } \\
\text { Range) }\end{array}$ & Delay (s) & Potential Influencing Factors & $\begin{array}{l}\text { Other EEG Monitoring } \\
\text { Included into the Device }\end{array}$ & $\begin{array}{l}\text { Additional } \\
\text { Parameters }\end{array}$ & Index Age Limits \\
\hline $\begin{array}{l}\text { BIS Monitor } \\
\text { (Bispectral Index } \\
\text { Monitor } \\
\text { Covidien LP, } \\
\text { Medtronic Inc.) } \\
\text { - } 2 \text { channel } \\
\text { - } 4 \text { channel }\end{array}$ & BIS index & $\begin{array}{l}\text { Analysis of EEG features } \\
\text { (degree of high frequency } \\
\text { activation, low frequency } \\
\text { synchronisation, nearly } \\
\text { suppressed periods, fully } \\
\text { suppressed periods) which } \\
\text { correlate with } \\
\text { hypnosis/sedations EEG in } \\
\text { adults }\end{array}$ & $\begin{array}{l}40-60(0-100) \\
0=\text { very deep } \\
\text { hypnosis; } \\
100=\text { conscious }\end{array}$ & $\begin{array}{l}\text { Index 5-15 } \\
\text { DSA } \\
\text { Real-time }\end{array}$ & $\begin{array}{l}\text { EMG and NMBDs } \\
\text { Medical Devices (Electocautery, } \\
\text { pacemakers, etc.) } \\
\text { Certain anaesthetic agentis or } \\
\text { adjuvants, } \\
\text { Serious clinical conditions } \\
\text { (cerebral ischemia, hypo perfusion, } \\
\text { cardiac arrest, hypovolemia, } \\
\text { hypotension, hypothermia) }\end{array}$ & $\begin{array}{l}2 \text { channel M: } \\
\text { Raw EEG } \\
4 \text { channel M: } \\
\text { - Raw-EEG } \\
\text { - DSA (Density Spectral } \\
\text { Array) } \\
\text { - Asymmetry (ASYM) } \\
\text { Indicator }\end{array}$ & $\begin{array}{l}\text { EMG (bar 0-4 }-> \\
\text { EMG power } 30 \text { to > } \\
\text { 55) } \\
\text { Burst Count } \\
\text { (Burst/minute) } \\
\text { SQI (Signal Quality } \\
\text { Indicator) 0-100 } \\
\text { Suppression Ratio } \\
\text { (SR) number }\end{array}$ & $\begin{array}{l}12 \text { year }=\text { safe } \\
1-5 \text { year to be cautiously used } \\
(2 \text { channel sensor age }>4 \text { years } \\
\text { recommended; } \\
\text { <1 year not safe } \\
\text { DSA }>6 \text { months }\end{array}$ \\
\hline \multirow[t]{2}{*}{$\begin{array}{l}\text { NARCOTREND- } \\
\text { Compact M } \\
\text { (Medival) }\end{array}$} & $\begin{array}{l}\text { Narcotrend } \\
\text { Monitor }\end{array}$ & \multirow{2}{*}{$\begin{array}{l}\text { Analysis of multivariate } \\
\text { EEG-derived parameters to } \\
\text { carry out an automatic } \\
\text { classification of the EEG on a } \\
\text { scale ranging } \\
\text { from stage A (conscious) to } \\
\text { stage F (very deep hypnosis). }\end{array}$} & $\begin{array}{l}\mathrm{D} \text { (general } \\
\text { anaesthesia)-E } \\
\text { (general } \\
\text { anaesthesia with } \\
\text { deep hypnosis); } \\
\text { [A (conscious)- F } \\
\text { (very deep } \\
\text { hypnosis)]. }\end{array}$ & Real-time & \multirow{2}{*}{$\begin{array}{l}\text { EMG and NMBDs } \\
\text { Medical Devices (Electocautery, } \\
\text { pacemakers, etc.) } \\
\text { Serious clinical conditions } \\
\text { (cerebral ischemia, hypo perfusion, } \\
\text { cardiac arrest, hypovolemia, } \\
\text { hypotension, hypothermia) }\end{array}$} & \multirow{2}{*}{$\begin{array}{l}\text { Raw-EEG ( } 1 \text { or } 2 \text { channels) } \\
\text { Cerebrogram } \\
\text { Relative Band } \\
\text { Activities/Power } \\
\text { Power Spectrum and DSA } \\
\text { Quantiles SEF50 (median } \\
\text { (50\% quantile) and SEF95 } \\
\text { spectral edge frequency } \\
\text { (95\% quantile) }\end{array}$} & \multirow{2}{*}{$\begin{array}{l}\text { EMG } \\
\text { Burst Suppression } \\
\text { Ratio (BSR) } \\
\text { STI (sharp transient } \\
\text { intensity) } \\
\text { Impedance }\end{array}$} & \multirow{2}{*}{$\begin{array}{l}<1 \text { year not safe } \\
<60 \text { days: only EEG classifications } \\
\text { for stages with implied or clear } \\
\text { suppression lines (E2 to F1). If } \\
\text { there is an EEG without } \\
\text { suppression lines, the output is } \\
\text { "Undiff. EEG" } \\
\mathbf{6 0} \text { day-1 year: the full A-F scale is } \\
\text { displayed. As long as no fully } \\
\text { classifiable EEG is detected -> the } \\
\text { output "Undiff. EEG" is displayed. } \\
\text { DSA }>6 \text { months }\end{array}$} \\
\hline & $\begin{array}{l}\text { Narcotrend } \\
\text { Index }\end{array}$ & & $\begin{array}{l}20-64(0-100) \\
0=\text { very deep } \\
\text { hypnosis; } \\
100=\text { conscious }\end{array}$ & $\begin{array}{l}\text { Index } 28 \\
\text { DSA } \\
\text { Real-time }\end{array}$ & & & & \\
\hline $\begin{array}{l}\text { E-ENTROPY } \\
\text { Module (GE } \\
\text { Healthcare, Inc.) }\end{array}$ & $\begin{array}{l}\text { SE (State of } \\
\text { Entropy) } \\
\text { RE (Repponse } \\
\text { Entropy) }\end{array}$ & $\begin{array}{l}\text { Analysis of the irregularity, } \\
\text { complexity, or unpredictability } \\
\text { characteristics of the EEG and } \\
\text { the frontal electromyograph } \\
\text { (FEMG) signals }\end{array}$ & $40-60(0-91)$ & $15-60$ & $\begin{array}{l}\text { Medical Devices (Electocautery, } \\
\text { pacemakers, etc.) } \\
\text { Neurological Disorders, traumas, } \\
\text { epileptic seizures and psychoactive } \\
\text { medication }\end{array}$ & - & $\begin{array}{l}\text { EMG (Index } \\
\text { component) } \\
\text { Burst Suppression } \\
\text { Ratio (BSR) }\end{array}$ & $<2$ year not safe \\
\hline $\begin{array}{l}\text { CSM Cerebral } \\
\text { State Monitor } \\
\text { (Danmeter) }\end{array}$ & $\begin{array}{l}\text { CSI (Cerebral } \\
\text { State Index) }\end{array}$ & $\begin{array}{l}\text { Quantitative EEG analysis in } \\
\text { specific frequency bands ( } \alpha \\
\text { and } \beta \text { ), the relationship } \\
\text { between these quantities ( } \beta-\alpha \text { ) } \\
\text { and the amount of } \\
\text { instantaneous burst } \\
\text { suppression (BS) in each } \\
\text { thirty-second period of the } \\
\text { EEG. }\end{array}$ & $\begin{array}{l}40-60 \\
(0-100) \\
0=\text { very deep } \\
\text { hypnosis; } \\
100=\text { conscious }\end{array}$ & 50 & $\begin{array}{l}\text { Serious clinical conditions (severe } \\
\text { neurological disorders) and } \\
\text { psychoactive medication } \\
\text { Medical Devices (Pacemakers) }\end{array}$ & Raw EEG & $\begin{array}{l}\text { EMG\% and EMG bar } \\
\text { BS\% Indicator (Burst } \\
\text { suppression } \\
\text { percentage } \\
\text { SQI (Signal Quality } \\
\text { Indicator) 0-100 } \\
\text { Sensor Impedance }\end{array}$ & $<2$ year not safe \\
\hline
\end{tabular}




\subsection{Limitations of $p E E G$ and DSA in Children}

In spite of the fact that they are taking hold also across paediatric anaesthesia standard practice, EEG-based monitors have some limitations, especially in infants (1-12 months) and neonates ( $<1$ months).

Age. The pEEG devices in current use rely on data from adult patients. Thus, their suitability to monitor anaesthesia depth in children is not well-defined, as the EEG changes accordingly with brain development. Only around the age of 12 years, the brain reaches its maturity as well as the stabilization of its electrical activity [25-28]. These age-related changes in the EEG, which mirror the synaptogenesis and myelination during the first year of life, also diminish the total DSA power and its representativeness of the depth of hypnosis in infants to the point that the devices currently in use cannot be deemed accurate and reliable in paediatric patients less than 6 months of age $[1,11,29,30]$.

Drugs. Anaesthetic agents affect the EEG-derived depth monitors resulting in a binary and non-specific modification of the index. Wang's study on single propofol anaesthesia in children, showed a linear correlation between propofol concentration and BIS value [26]. Conversely, those on inhalation anaesthesia with sevoflurane demonstrated a decrease in BIS value when the concentration of sevoflurane increased from 0 to $4 \%$, but a paradoxical increase when the volatile anaesthetic rose to values above $4 \%$. An increase in BIS and entropy was also observed during ketamine anaesthesia. This was paradoxically linked to a deeper hypnosis [31]. Dexmedetomidine leads to a decrease in the BIS value when used together with sevoflurane or propofol to induce general anaesthesia [32,33] while discordant data derive from studies on $\mathrm{N}_{2} \mathrm{O}$ and pEEG monitors [34,35]. Neuromuscular blockers (NMBs) lead to a rapid decrease in BIS in adults. This probably happens due to the impact of NMBs on EMG activity [36]. Finally, whether opioids affect BIS is neither well-defined nor consistent $[37,38]$. However, this could be explained by the fact that the nociception neuronal pathway is not well-detected through cortical EEG-based monitors [7]. Raw EEG and spectrogram analysis, instead, allow an experienced physician to recognize the specific effects that each anaesthetic has on the brain's cortical electrical activity. This usually reflects the drug's mechanism of action [29].

Neurological Diseases. Caution should be paid when EEG-derived monitors are applied in children with neurological diseases such as congenital metabolic and genetic disorders and acquired diseases, such as post-hypoxic encephalopathy or neurodegenerative disorders of unknown origin because lower BIS values and a greater tendency to burst suppression at comparable doses of anaesthetic has been described in these patients [2-4]. This is likely related to epileptic and non-epileptic EEG anomalies caused by the underlying neurological disorder [2]; however, the same effect may also be due to the use of drugs that act on the nervous system such as antiepileptics or neuroleptics. Nonetheless, not only can the EEG monitors be used, but also they are extremely useful in those patients whose communication problems and severe underlying neurological impairment can make it difficult to assess an adequate level of anaesthesia [3].

\section{Near Infrared Spectroscopy (NIRS) in Children}

One of the goals of good intraoperative care is to maintain adequate cardiac output and delivery of oxygen to the tissues, particular to the brain. Monitoring of the standard vital signs provides information about end-organ perfusion, but lacks specificity for brain perfusion. Blood pressure measurements during anaesthesia are often used as a proxy for organ perfusion, but it has been found inaccurate, especially in neonates and infants [39]. We know that hypotension is one of the perioperative risks related to neurocognitive developmental issues in this population [40]. However, the way cerebral autoregulation is maintained is multifactorial. Arterial blood pressure is only one of the contributing factors and it cannot be used as a surrogate for organ perfusion in general and specifically for brain perfusion.

Real-time near infrared spectroscopy (NIRS) noninvasively measures cerebral oxygen saturation $\left(\mathrm{SCO}_{2}\right)$ in the tissue approximately 1 to $2 \mathrm{~cm}$ below the sensor. This method is 
based on the high degree of transparency of brain tissue in the near-infrared range. Even though NIRS reads haemoglobin saturation in all the vessels located in the portion of the tissue scanned (arterioles, venules, and capillaries), it is a surrogate of venous saturation because venous volume counts for about $75 \%$ to $85 \%$ of the total cerebral blood volume and only $15 \%$ to $25 \%$ of it is arterial. Cerebral oximetry using NIRS technology has been validated against jugular venous oxygen saturations, even in children with congenital heart disease, with a correlation coefficient between jugular venous bulb saturations and cerebral oximetry as high as 0.8 to 0.9 in some studies but as low as 0.5 in others [41,42].

\subsection{Population Target}

The application of cerebral NIRS in children under anaesthesia has not yet become a clinical standard of care, even though a growing body of evidence suggests that NIRS can be very useful in detecting cerebral desaturation in particular population and for specific type of surgery. NIRS can be a valuable tool in neonates and infants as they are more vulnerable to neurological complications related to disruption of cerebral homeostasis [43]. In particular, preterm infants have anatomically incomplete and underdeveloped cerebral vasculature that cannot yet autoregulate fully [44]. Some studies of cerebral autoregulation in neonates point out a correlation between impaired cerebral autoregulation and clinical outcome $[45,46]$. Therefore, it might be crucial to be able to adequately and safely assess the autoregulatory capacity and to detect and prevent unnoticed cerebral hypo- or hyperperfusion and secondary brain injury. NIRS might fulfil these requirements and can be used to measure regional cerebral oxygenation as a surrogate for disruption of autoregulation.

It is also known that cardiac surgery and cardiopulmonary bypass itself are associated with dysfunctional autoregulation [47]. In this context, fluctuation of $\mathrm{ScO}_{2}$ from baseline may represent an imbalance between oxygen supply and demand. It has been shown that these changes occur before lactic acidosis or hemodynamic compromise are established $[48,49]$. This has been suggested based on findings that correlate occurrence and duration of cerebral desaturation intraoperatively with low cardiac output state and elevated lactate levels as well as increased mortality [50-52]. Moreover, NIRS works effectively also in non-pulsatile circumstances, like during CPB, other low-flow states and during hypothermic circulatory arrest [53].

Despite numerous studies have shown that low $\mathrm{ScO}_{2}$ can anticipate later signs of imbalanced oxygen delivery/consumption, the long-term benefit of this approach has yet to be elucidated. A 2009 systematic review of cerebral NIRS in paediatric cardiac surgical patients including 38 trials found no evidence that cerebral NIRS monitoring improved patient outcomes [54]. Since this review, no new studies have been conducted that demonstrate that changes in cerebral oximetry prompt interventions that improve clinical outcomes. This is likely to be related with lack of clarity on the threshold value below which risks increase.

Evidence supporting the benefit of NIRS monitoring in noncardiac surgical procedures are still very discordant. On one hand, the majority of papers delineating the use of NIRS monitoring during major noncardiac paediatric surgery have been published in surgical journals. In these studies, NIRS was mainly used as a monitoring tool to address possible safety issues of new surgical techniques, such as thoracoscopic repair of congenital diaphragmatic hernia or oesophageal atresia [55-57]. On the other hand, the use of NIRS has been triggered by the issue of anaesthesia neurotoxicity in children less than 3 years of age. Early studies have been conducted with the aim of identifying incidence and associated factors of cerebral desaturation in children undergoing anaesthesia for non-cardiac surgery and therefore see if any undetectable cerebral desaturation could be a risk factor in the anaesthesia-related neurotoxicity. It has been shown that in children less than 2 years of age, $\mathrm{ScO}_{2}$ usually increased with sevoflurane induction of anaesthesia. Nonetheless, when significant hypotension occurred at induction, $\mathrm{ScO}_{2}$ decreased, and this happened mainly in younger children [58-60]. These studies suggest that unrecognized cerebral desaturation during anaesthesia of infants occurs frequently and is often associated with hypotension. 
Two more recent studies have found different results. Olbrecht et al. [61] described the incidence of cerebral desaturation in 453 infants less than 6 months of age undergoing a wide range of non-cardiac procedures. Severe desaturation (below $50 \%$ absolute value or greater than $30 \%$ below baseline) was present in $2 \%$ of the population observed, but it was poorly associated with low mean arterial pressure. Their conclusion was that unrecognized severe cerebral desaturation is uncommon. Gomez-Pesquera et al. [62] investigated the relationship between cerebral oxygenation and negative postoperative behavioural changes (NPOBC) 7 days after surgery in children between 2 and 12 years of age. They showed an association between decreased cerebral oxygenation and the incidence of NPOBC, though not for patients experiencing the biggest desaturations ( $>20 \%$ below baseline).

\section{2. $\mathrm{ScO}_{2}$ Values and Trigger for Intervention}

When using NIRS technology, it is important to understand the relevant physiological parameters contributing to cerebral regional oxygen saturation, which are heart rate, blood pressure, oxygen saturation, and carbon dioxide partial pressure Figure 2. All these variables need to be considered during interpretation of NIRS and its changes can only be interpreted together with standard vital signs monitoring. In a recent editorial, Skowno et al. referred to NIRS as a "multidimensional monitor" because it is influenced by multiple variables and its understanding relies on these variables [63]. Imbalance between oxygen demand and supply as well as ventilation can be detected early in the context of changes in cerebral NIRS while standard monitoring parameters can help identifying the causes of $\mathrm{ScO}_{2}$ changes. Therefore, interventions can be made in a timely matter in order to prevent potentially life-threatening complications or at least reduce their severity. It is important to highlight that a decrease in $\mathrm{ScO}_{2}$ can be also due to low haemoglobin concentrations following acute blood loss even before haemodynamic instability occurs. Anaemia becomes relevant for $\mathrm{ScO}_{2}$ when haemoglobin levels are not adequate to deliver an oxygen-carrying capacity that meets the demands of cerebral oxygen consumption. Transfusion of red blood cells has been shown to result in increased $\mathrm{ScO}_{2}$ values [64].

Values of $\mathrm{ScO}_{2}$ within normal range vary in relationship with patient population and NIRS instrumentation, with high interindividual and intraindividual variability. Mean ( \pm standard deviation) values for $\mathrm{ScO}_{2}$ in healthy children are $68 \% \pm 10 \%$ and in infants $64 \% \pm 5 \%[65,66]$. Determination of what constitutes a critical $\mathrm{ScO}_{2}$ value depends on the identification of a hypoxic-ischemic threshold, beyond which ongoing hypoxia and/or ischemia leads to neurophysiologic impairment, cerebral metabolic failure, and irreversible morphologic damage. It is unknown what the exact individual lower safety margin of $\mathrm{ScO}_{2}$ values in children is. Data from animal studies suggest that the severity and the duration of low cerebral oxygenation are the main leading factors to cerebral damage $[67,68]$.

\section{3. $\mathrm{ScO}_{2}$ and Clinical Algorithms}

Despite scientific efforts, it has not yet been possible to define individual lower limit of $\mathrm{ScO}_{2}$ values. This uncertainty applies in an anaesthetic clinical setting, where it is difficult to identify a $\mathrm{ScO}_{2}$ value that should trigger intervention. Because of it, anaesthetists base their approach on personal experiences.

Few algorithms have been published in order to guide the NIRS use, interpretation and intervention. They are all based not on scientific evidence, but on practical approaches led by physiological and pathological knowledge and common sense. Kurth et al. consider $60 \%$ to $80 \%$ as a normal range for $\mathrm{ScO}_{2}$, and because functional impairment begins at an $\mathrm{ScO}_{2}$ of about $45 \%$ (albeit in piglets), there is a buffer zone between $45 \%$ and $60 \%$ whereby cerebral oxygenation is adequate for function, but lower than normal [68]. Decreasing $\mathrm{ScO}_{2}$ and/or absolute values below the buffer zone necessitates prompt re-evaluation of the patient.

Denault et al. [69] published a proposed clinical algorithm to respond to changes in cerebral oximetry, using clinical parameters including blood pressure, arterial saturation, carbon dioxide tension and haemoglobin. The algorithm has been developed for adult 
patients, and its use cannot be validated in the paediatric population because there are insufficient data to support this interventional algorithm in this population.

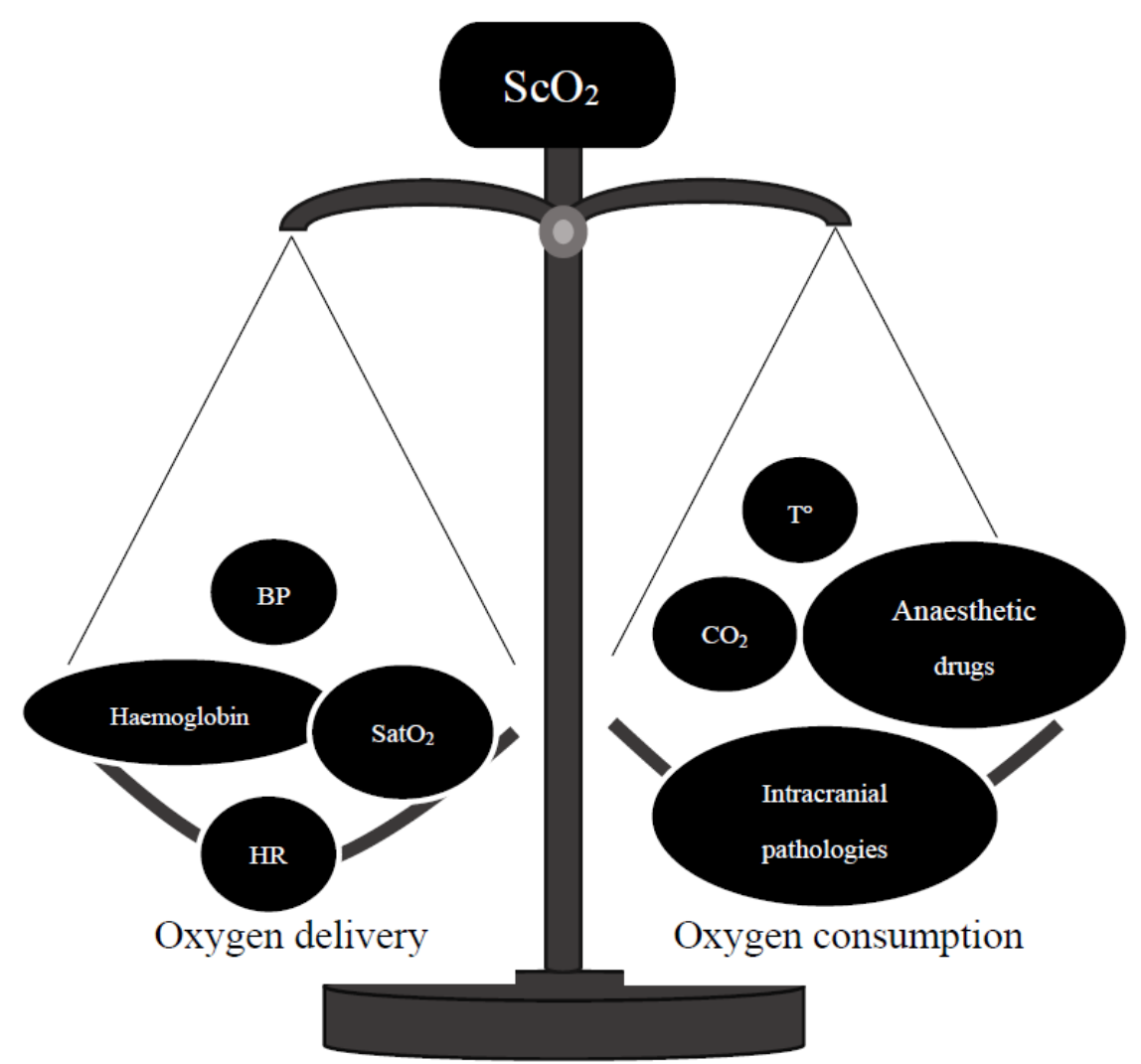

Figure 2. Cerebral oxygen delivery and consumption balance and contributing factors to cerebral oxygen saturation during anaesthesia. $\mathrm{HR}$, heart rate; $\mathrm{BP}$, blood pressure; $\mathrm{SatO}_{2}$, oxygen saturation; $\mathrm{CO}_{2}$, carbon dioxide; $\mathrm{T}^{\circ}$, temperature; $\mathrm{ScO}_{2}$ cerebral oxygen saturation.

Weber F et al. developed the "Baseline-Bottomline Approach" as NIRS-directed haemodynamic management [70]. It differs fundamentally from all previously published approaches, as it defines a baseline $\mathrm{ScO}_{2}$ value, registered in the awake child prior to anaesthesia induction, as the lowest acceptable limit during anaesthesia and surgery. The strategy to ensure adequate cerebral perfusion and oxygen delivery uses cerebral $\mathrm{SO}_{2}$ as the single target parameter, while blood pressure, heart rate, $\mathrm{PaCO}_{2}$, and $\mathrm{SaO}_{2}$ are contributing parameters that determine the $\mathrm{ScO}_{2}$. The aim of this approach is to maintain $\mathrm{ScO}_{2}$ at or above awake baseline, adjusting and correcting the contributing variables. Basically, they aim at maintenance of an optimal condition rather than treatment of potentially harmful cerebral desaturation.

\section{Conclusions}

EEG-derived anaesthesia depth monitors perform well in children that should be applied for guiding clinicians in providing the correct dose of general anaesthetics. However, clinicians should be trained on the specific device applied with its own technology, in order to draw the right interpretation. Moreover, age, type of anaesthesia and underlying neurologic conditions should guide clinicians to correctly titrate medications, beyond the monitoring result by itself.

NIRS and brain oxygenations monitoring represent a relatively recent technological advancement. It is clear that acute drop in brain oxygenation will have an impact on the neurological outcome, but the specific intervention that should be applied for acute derangements is still to be validated. NIRS can monitor brain oxygenation in the area where the sensor is applied, and it should not be interpreted as a surrogate index of brain 
autoregulation. In fact, the limits of autoregulation may vary according to the age, but also to the other physiological parameters. Then, NIRS should be clinically interpreted under the light a more comprehensive clinical condition, which might evolve time by time during anaesthesia and surgery. Nevertheless, both monitoring should be implemented in the daily practice, especially when the most fragile population is treated. Understanding the physiology and pathophysiology of brain autoregulation will be the next step of clinical research to define the limits of tolerance. Right now, clinicians should bear in mind that keeping young patients as close as possible to the baseline parameters is mandatory to stay away from the edge of loss of autoregulation.

Funding: This research received no external funding.

Institutional Review Board Statement: Not applicable.

Informed Consent Statement: Not applicable.

Data Availability Statement: Not applicable.

Conflicts of Interest: The authors declare no conflict of interest.

\section{References}

1. Cornelissen, L.; Kim, S.E.; Lee, J.M.; Brown, E.N.; Purdon, P.L.; Berde, C.B. Electroencephalographic markers of brain development during sevoflurane anaesthesia in children up to 3 years old. Br. J. Anaesth. 2018, 120, 1274-1286. [CrossRef]

2. Valkenburg, A.J.; De Leeuw, T.G.; Tibboel, D.; Weber, F. Lower bispectral index values in children who are intellectually disabled. Anaest. Analg. 2009, 109, 1428-1433. [CrossRef] [PubMed]

3. Brandt, S.P.; Walsh, E.C.; Cornelissen, L.; Lee, J.M.; Berde, C.; Shank, E.S.; Purdon, P.L. Case Studies Using the Electroencephalogram to Monitor Anesthesia-Induced Brain States in Children. Anesth. Analg. 2020, 131, 1043-1056. [CrossRef] [PubMed]

4. Walsh, E.C.; Lee, J.M.; Terzakis, K.; Zhou, D.W.; Burns, S.; Buie, T.M.; Firth, P.G.; Shank, E.S.; Houle, T.T.; Brown, E.N. Agedependent changes in the propofol-induced electroencephalogram in children with autism spectrum disorder. Front. Syst. Neurosci. 2018, 12, 23. [CrossRef] [PubMed]

5. Rigouzzo, A.; Khoy-Ear, L.; Laude, D.; Louvet, N.; Moutard, M.-L.; Sabourdin, N.; Constant, I. EEG profiles during general anesthesia in children: A comparative study between sevoflurane and propofol. Paediatr. Anaesth. 2019, 29, 250-257. [CrossRef]

6. Davidson, A.; Huang, G.; Rebmann, C.; Ellery, C. Performance of entropy and Bispectral Index as measures of anaesthesia effect in children of different ages. Br. J. Anaesth. 2005, 95, 674-679. [CrossRef]

7. Davidson, A.; Skowno, J. Neuromonitoring in paediatric anaesthesia. Curr. Opin. Anaesthesiol. 2019, 32, 370-376. [CrossRef]

8. Lee, J.M.; Akeju, O.; Terzakis, K.; Pavone, K.J.; Deng, H.; Houle, T.T.; Firth, P.G.; Shank, E.S.; Brown, E.N.; Purdon, P.L. A prospective study of age-dependent changes in propofol-induced electroencephalogram oscillations in children. Anesthesiology 2017, 127, 293-306. [CrossRef]

9. Purdon, P.L.; Sampson, A.; Pavone, K.J.; Brown, E.N. Clinical Electroencephalography for Anesthesiologists: Part I: Background and Basic Signatures. Anesthesiology 2015, 123, 937-960. [CrossRef]

10. Maja, V.; Talja, P.; Tenkanen, N.; Tolvanen-Laakso, H. Description of the Entropy algorithm as applied in the Datex-Ohmeda S/5 Entropy Module. Acta Anaesthesiol. Scand. 2004, 48, 154-161.

11. De Heer, I.J.; Bouman, S.J.M.; Weber, F. Electroencephalographic (EEG) density spectral array monitoring in children during sevoflurane anaesthesia: A prospective observational study. Anaesthesia 2019, 74, 45-50. [CrossRef]

12. Zanner, R.; Pilge, S.; Kochs, E.F.; Kreuzer, M.; Schneider, G. Time delay of electroencephalogram index calculation: Analysis of cerebral state, bispectral, and Narcotrend indices using perioperatively recorded electroencephalographic signals. Br. J. Anaesth. 2009, 103, 394-399. [CrossRef]

13. Myles, P.S.; Leslie, K.; McNeil, J.; Forbes, A.; Chan, M.T.V.; B-Aware Trial Group. Bispectral index monitoring to prevent awareness during anaesthesia: The B-Aware randomised controlled trial. Lancet 2004, 363, 1757-1763. [CrossRef]

14. Avidan, M.S.; Zhang, L.; Burnside, B.A.; Finkel, K.J.; Searleman, A.; Selvidge, J.A.; Saager, L.; Turner, M.S.; Rao, S.; Bottros, M.; et al. Anesthesia awareness and the bispectral index. N. Engl. J. Med. 2008, 358, 1097-1108. [CrossRef] [PubMed]

15. Gan, T.J.; Glass, P.S.; Windsor, A.; Payne, F.; Rosow, C.; Sebel, P.; Manberg, P. Bispectral index allows faster emergence and improved recovery from propofol, alfentanil, and nitrous oxide anesthesia. BIS Utility Study Group. Anesthesiology. 1997, 87, 808-815. [CrossRef]

16. Liu, S.S. Effects of Bispectral Index monitoring on ambulatory anesthesia: A meta-analysis of randomised controlled trials and a cost analysis. Anesthesiology 2004, 101, 311-315. [CrossRef] [PubMed]

17. Oliveira, C.R.; Bernardo, W.M.; Nunes, V.M. Benefit of general anesthesia monitored by bispectral index compared with monitoring guided only by clinical parameters. Systematic review and meta-analysis. Braz. J. Anesthesiol. 2017, 67, 72-84. [CrossRef] [PubMed] 
18. Sargin, M.; Uluer, M.S.; Ozmen, S. The effects of bispectral index monitoring on hemodynamics and recovery profile in developmentally delayed pediatric patients undergoing dental surgery. Paediatr. Anaesth. 2015, 950-955. [CrossRef]

19. Weber, F.; Walhout, L.C.; Escher, J.C. The impact of narcotrend EEG-guided propofol administration on the speed of recovery from pediatric procedural sedation-a randomized controlled trial. Paediatr. Anaesth. 2018, 28, 443-449. [CrossRef]

20. Vance, J.L.; Shanks, A.M.; Woodrum, D.T. Intraoperative bispectral index monitoring and time to extubation after cardiac surgery: Secondary analysis of a randomized controlled trial. BMC Anesthesiol. 2014, 14, 79. [CrossRef] [PubMed]

21. Sury, M.R. Accidental awareness during anesthesia in children. Paediatr. Anaesth. 2016, 26, 468-474. [CrossRef]

22. Yuan, I.; Olbrecht, V.A.; Mensinger, J.L.; Zhang, B.; Davidson, A.J.; Von Ungern-Sternberg, B.S.; Skowno, J.; Lian, Q.; Song, X.; Zhao, P. Statistical Analysis Plan for "An international multicenter study of isoelectric electroencephalography events in infants and young children during anesthesia for surgery". Paediatr. Anaesth. 2019, 29, 243-249. [CrossRef]

23. Cheung, Y.M.; Scoones, G.; Stolker, R.J.; Weber, F. Use, applicability and reliability of depth of hypnosis monitors in children-a survey among members of the European Society for Paediatric Anaesthesiology. BMC Anesthesiol. 2018, 18, 40. [CrossRef]

24. Anderson, B.J.; Bagshaw, O. Practicalities of Total Intravenous Anesthesia and Target-controlled Infusion in Children. Anesthesiology 2019, 131, 164-185. [CrossRef]

25. Eisermann, M.; Kaminska, A.; Moutard, M.L.; Soufflet, C.; Plouin, P. Normal EEG in childhood: From neonates to adolescents. Neurophysiol. Clin. 2013, 43, 35-65. [CrossRef] [PubMed]

26. Wang, F.; Zhang, J.; Yu, J.; Tian, M.; Cui, X.; Wu, A. Variation of bispectral index in children aged 1-12 years under propofol anesthesia: An observational study. BMC Anesthesiol. 2019, 19, 145. [CrossRef]

27. Sciusco, A.; Standing, J.F.; Sheng, Y.; Raimondo, P.; Cinnella, G.; Dambrosio, M. Effect of age on the performance of bispectral and entropy indices during sevoflurane pediatricanesthesia: A pharmacometric study. Paediatr. Anaesth. 2017, 27, 399-408. [CrossRef] [PubMed]

28. Dennhardt, N.; Arndt, S.; Beck, C.; Boethig, D.; Heiderich, S.; Schultz, B.; Weber, F.; Sümpelmann, R. Effect of age on Narcotrend Index monitoring during sevoflurane anesthesia in children below 2 years of age. Paediatr. Anaesth. 2018, 28, 112-119. [CrossRef] [PubMed]

29. Purdon, P.; Pavone, K.; Akeju, O.; Smith, A.; Sampson, A.; Lee, J.; Zhou, D.; Solt, K.; Brown, E. The Ageing Brain: Age-dependent changes in the electroencephalogram during propofol and sevoflurane general anaesthesia. Br. J. Anaesth. 2015, 115, i46-i57. [CrossRef] [PubMed]

30. Hayashi, K.; Shigemi, K.; Sawa, T. Neonatal electroencephalography shows low sensitivity to anesthesia. Neurosci. Lett. 2012, 517, 87-91. [CrossRef]

31. Hans, P.; Dewandre, P.Y.; Brichant, J.F.; Bonhomme, V. Comparative effects of ketamine on Bispectral Index and spectral entropy of the electroencephalogram under sevoflurane anaesthesia. Br. J. Anaesth. 2005, 94, 336-340. [CrossRef]

32. Wang, T.; Ge, S.; Xiong, W.; Zhou, P.; Cang, J.; Xue, Z. Effects of different loading doses of dexmedetomidine on bispectral index under stepwise propofol target-controlled infusion. Pharmacology 2013, 91, 1-6. [CrossRef]

33. Ozcengiz, D.; Unlügenç, H.; Güneş, Y.; Karacaer, F. The effect of dexmedetomidine on bispectral index monitoring in children. Middle East. J. Anaesthesiol. 2012, 21, 613-618.

34. Prabhakar, H.; Ali, Z.; Bithal, P.K.; Singh, G.P.; Laithangbam, P.K.; Dash, H.H. EEG entropy values during isoflurane, sevoflurane and halothane anesthesia with and without nitrous oxide. J. Neurosurg. Anesthesiol. 2009, 21, 108-111. [CrossRef] [PubMed]

35. Hans, P.; Dewandre, P.Y.; Brichant, J.F.; Bonhomme, V. Effects of nitrous oxide on spectral entropy of the EEG during surgery under balanced anaesthesia with sufentanil and sevoflurane. Acta Anaesthesiol. Belg. 2005, 56, 37-43. [PubMed]

36. Schuller, P.J.; Newell, S.; Strickland, P.A.; Barry, J.J. Response of bispectral index to neuromuscular block in awake volunteers. Br. J. Anaesth. 2015, 115, i95-i103. [CrossRef]

37. Schmidt, G.N.; Bischoff, P.; Standl, T.; Lankenau, G.; Hilbert, M.; Esch, J.S.A. Comparative Evaluation of Narcotrend, Bispectral Index, and Classical Electroencephalographic Variables During Induction, Maintenance, and Emergence of a Propofol/Remifentanil Anesthesia. Anesth. Analg. 2004, 98, 1346-1353. [CrossRef] [PubMed]

38. Minto, C.F.; Schnider, T.W.; Egan, T.D.; Youngs, E.; Lemmens, H.J.; Gambus, P.L.; Billard, V.; Hoke, J.F.; Moore, K.H.; Hermann, D.J.; et al. Influence of age and gender on the pharmacokinetics and pharmacodynamics of remifentanil. I. Model development. Anesthesiology 1997, 86, 10-23. [CrossRef] [PubMed]

39. De Graaff, J.C. Intraoperative blood pressure levels in young and anaesthetised children: Are we getting any closer to the truth? Curr. Opin. Anaesthesiol. 2018, 31, 313-319. [CrossRef] [PubMed]

40. McCann, M.E.; Schouten, A.N. Beyond survival; influences of blood pressure, cerebral perfusion and anesthesia on neurodevelopment. Paediatr. Anaesth. 2014, 24, 68-73. [CrossRef]

41. Nagdyman, N.; Fleck, T.; Schubert, S.; Ewert, P.; Peters, B.; Lange, P.E.; Abdul-Khaliq, H. Comparison between cerebral tis- sue oxygenation index measured by near-infrared spectroscopy and venous jugular bulb saturation in children. Intensive Care Med. 2005, 31, 846-850. [CrossRef]

42. Nagdyman, N.; Ewert, P.; Peters, B.; Miera, O.; Fleck, T.; Berger, F. Comparison of different near-infrared spectroscopic cerebral oxygenation indices with central venous and jugular venous oxygenation saturation in children. Paediatr. Anaesth. 2008, 18, 160-166. [CrossRef] 
43. Suemori, T.; Skowno, J.; Horton, S.; Bottrell, S.; Butt, W.; Davidson, A.J. Cerebral oxygen saturation and tissue hemoglobin concentration as predictive markers of early postoperative outcomes after pediatric cardiac surgery. Paediatr. Anaesth. 2016, 26, 182-189. [CrossRef] [PubMed]

44. Rhee, C.J.; Da Costa, C.S.; Austin, T.; Brady, K.M.; Czosnyka, M.; Lee, J.K. Neonatal cerebrovascular autoregulation. Pediatr. Res. 2018, 84, 602-610. [CrossRef] [PubMed]

45. Soul, J.S.; Hammer, P.E.; Tsuji, M.; Saul, J.P.; Bassan, H.; Limperopoulos, C.; Disalvo, D.N.; Moore, M.; Akins, P.; Ringer, S.; et al. Fluctuating pressure-passivity is common in the cerebral circulation of sick premature infants. Pediatr. Res. 2007, 61, 467-473. [CrossRef] [PubMed]

46. Wong, F.Y.; Leung, T.S.; Austin, T.; Wilkinson, M.; Meek, J.H.; Wyatt, J.S.; Walker, A.M. Impaired autoregulation in preterm infants identified by using spatially resolved spectroscopy. Pediatrics 2008, 121, e604-e611. [CrossRef] [PubMed]

47. Bassan, H.; Gauvreau, K.; Newburger, J.W.; Tsuji, M.; Limperopoulos, C.; Soul, J.S.; Walter, G.; Laussen, P.C.; Jonas, R.A.; Du Plessis, A.J. Identification of pressure passive cerebral perfusion and its mediators after infant cardiac surgery. Pediatr. Res. 2005, 57, 35-41. [CrossRef] [PubMed]

48. Menke, J.; Moller, G. Cerebral near-infrared spectroscopy correlates to vital parameters during cardiopulmonary bypass surgery in children. Pediatr. Cardiol. 2014, 35, 155-163. [CrossRef] [PubMed]

49. Kussman, B.D.; Laussen, P.C.; Benni, P.B.; McGowan, F.X.; McElhinney, D.B. Cerebral oxygen saturation in children with congenital heart disease and chronic hypoxemia. Anesth. Analg. 2017, 125, 234-240. [CrossRef]

50. Zulueta, J.L.; Vida, V.L.; Perisinotto, E.; Pittarello, D.; Stellin, G. Role of intraoperative regional oxygen saturation using near infrared spectroscopy in the prediction of low output syndrome after pediatric heart surgery. J. Card. Surg. 2013, 28, 446-452. [CrossRef]

51. Chakravarti, S.B.; Mittnacht, A.J.; Katz, J.C.; Nguyen, K.; Joashi, U.; Srivastava, S. Multisite near-infrared spectroscopy predicts elevated blood lactate level in children after cardiac surgery. J. Cardiothorac. Vasc. Anesth. 2009, 23, 663-667. [CrossRef] [PubMed]

52. Vida, V.L.; Tessari, C.; Cristante, A.; Nori, R.; Pittarello, D.; Ori, C.; Cogo, P.; Perissinotto, E.; Stellin, G. The role of regional oxygen saturation using near-infrared spectroscopy and blood lactate levels as early predictors of outcome after pediatric cardiac surgery. Can. J. Cardiol. 2016, 32, 970-977. [CrossRef]

53. Andropoulos, D.B.; Diaz, L.K.; Fraser, C.D., Jr.; McKenzie, E.D.; Stayer, S.A. Is bilateral monitoring of cerebral oxygen saturation necessary during neonatal aortic arch reconstruction? Anesth. Analg. 2004, 98, 1267-1272. [CrossRef] [PubMed]

54. Hirsch, J.C.; Charpie, J.R.; Ohye, R.G. Near-infrared spectroscopy: What we know and what we need to know-A systematic review of the congenital heart disease literature. J. Thorac. Cardiovasc. Surg. 2009, 137, 154-159. [CrossRef] [PubMed]

55. Bishay, M.; Giacomello, L.; Retrosi, G.; Thyoka, M.; Garriboli, M.; Brierley, J.; Harding, L.; Scuplak, S.; Cross, K.M.; Curry, J.I.; et al. Hypercapnia and acidosis during open and thoracoscopic repair of congenital diaphragmatic hernia and esophageal atresia: Results of a pilot randomized controlled trial. Ann. Surg. 2013, 258, 895-900. [CrossRef] [PubMed]

56. Bishay, M.; Giacomello, L.; Retrosi, G.; Thyoka, M.; Nah, S.A.; McHoney, M.; De Coppi, P.; Brierley, J.; Scuplak, S.; Kiely, E.M.; et al. Decreased cerebral oxygen saturation during thoracoscopic repair of congenital diaphragmatic hernia and esophageal atresia in infants. J. Pediatr. Surg. 2011, 46, 47-51. [CrossRef]

57. Costerus, S.; Vlot, J.; Van Rosmalen, J.; Wijnen, R.; Weber, F. Effects of neonatal thoracoscopic surgery on tissue oxygenation: A pilot study on (Neuro-) monitoring and outcomes. Eur. J. Pediatr. Surg. 2019, 29, 166-172.

58. Rhondali, O.; Juhel, S.; Mathews, S.; Cellier, Q.; Desgranges, F.P.; Mahr, A.; De Queiroz, M.; Pouyau, A.; Rhzioual-Berrada, K.; Chassard, D. Impact of sevoflurane anesthesia on brain oxygenation in children younger than 2 years. Paediatr. Anaesth. 2014, 24, 734-740. [CrossRef]

59. Michelet, D.; Arslan, O.; Hilly, J.; Mangalsuren, N.; Brasher, C.; Grace, R.; Bonnard, A.; Malbezin, S.; Nivoche, Y.; Dahmani, S. Intraoperative changes in blood pressure associated with cerebral desaturation in infants. Paediatr. Anaesth. 2015, 25, 681-688. [CrossRef]

60. Koch, H.W.; Hansen, T.G. Perioperative use of cerebral and renal near-infrared spectroscopy in neonates: A 24-h observational study. Paediatr. Anaesth. 2016, 26, 190-198. [CrossRef]

61. Olbrecht, V.A.; Skowno, J.; Marchesini, V.; Ding, L.; Jiang, Y.; Ward, C.G.; Yu, G.; Liu, H.; Schurink, B.; Vutskits, L.; et al. An international, multicenter, observational study of cerebral oxygenation during infant and neonatal anesthesia. Anesthesiology 2018, 128, 85-96. [CrossRef]

62. Gómez-Pesquera, E.; Poves-Alvarez, R.; Martinez-Rafael, B.; Liu, P.; Alvarez, J.; Lorenzo-López, M.; Fierro, I.; Gómez-Sánchez, E.; Heredia-Rodriguez, M.; Gómez-Herreras, J.I.; et al. Cerebral Oxygen Saturation and Negative Postoperative Behavioral Changes in Pediatric Surgery: A Prospective Observational Study. J. Pediatr. 2019, 208, 207-213. [CrossRef] [PubMed]

63. Skowno, J.; Vutskits, L.; McGowan, F.; Kurth, C.D. Staying away from the edge-cerebral oximetry guiding blood pressure management. Paediatr. Anaesth. 2015, 25, 654-655. [CrossRef]

64. Bailey, S.M.; Hendricks-Munoz, K.D.; Wells, J.T.; Mally, P. Packed red blood cell transfusion increases regional cerebral and splanchnic tissue oxygen saturation in anemic symptomatic preterm infants. Am. J. Perinatol. 2010, 27, 445-453. [CrossRef] [PubMed]

65. Kurth, C.; Steven, J.L.; Montenegro, L.M.; Watzman, H.; Gaynor, J.; Spray, T.L.; Nicolson, S.C. Cerebral oxygen saturation before congenital heart surgery. Ann. Thorac. Surg. 2001, 72, 187-192. [CrossRef] 
66. Franceschini, M.A.; Thaker, S.; Themelis, G.; Krishnamoorthy, K.K.; Bortfeld, H.; Diamond, S.G.; Boas, D.A.; Arvin, K.; Grant, P.E. Assessment of infant brain development with frequency-domain near-infrared spectroscopy. Pediatr. Res. 2007, 61, 546-551. [CrossRef]

67. Kurth, C.D.; Levy, W.J.; McCann, J. Near-infrared spectroscopy cerebral oxygen saturation thresholds for hypoxia-ischemia in piglets. J. Cereb. Blood Flow Metab. 2002, 22, 335-341. [CrossRef]

68. Kurth, C.D.; McCann, J.C.; Wu, J.; Miles, L.; Loepke, A.W. Cerebral oxygen saturation-time threshold for hypoxic-ischemic injury in piglets. Anesth. Analg. 2009, 108, 1268-1277. [CrossRef] [PubMed]

69. Denault, A.; Deschamps, A.; Murkin, J.M. A proposed algorithm for the intra-operative use of cerebral near-infrared spectroscopy. Semin. Cardiothorac. Vasc. Anesth. 2007, 11, 274-281. [CrossRef]

70. Weber, F.; Scoones, G.P. A practical approach to cerebral near-infrared spectroscopy (NIRS) directed hemodynamic management in non cardiac pediatricanesthesia. Pediatr. Anesth. 2019, 29, 993-1001. [CrossRef] 